\title{
Silicon-enriched hydroxyapatite formed induced by REFIX-based toothpaste on the enamel surface
}

\author{
Formação de hidroxiapatita enriquecida com silício induzida por dentifrício à base de REFIX na superfície do esmalte \\ Fabiano Vieira VILHENA ${ }^{1}$ (), Audrey Alesandra Singhen Garcia LONNI ${ }^{2}$ (D), Paulo Henrique Perlatti D’ALPINO ${ }^{3}$ (1) \\ 1 - Trials, Research and Development, Inc. São Paulo, SP, Brazil. \\ 2 - Universidade Estadual de Londrina, Centro de Ciências da Saúde, Departamento de Ciências Farmacêuticas. Londrina, PR, Brazil. \\ 3 - Triplet Biotechnology Solutions. São Paulo, SP, Brazil.
}

\begin{abstract}
Objective: This in vitro study aimed at characterizing the mineral content and filler particle morphology of a fluoridated toothpaste containing REFIX technology and the mineral content and the morphology of the enamel surface treated with this product. Material and Methods: Bovine enamel blocks $(n=5)$ were obtained $(4 \times 4 \times 6 \mathrm{~mm})$, demineralized (artificial caries lesion), and treated ( $\mathrm{pH}$ cycling and brushing with the toothpaste). During the $\mathrm{pH}$ cycling, which lasted for 7 days (demineralization and remineralization took $6 \mathrm{~h}$ and $18 \mathrm{~h}$, respectively), the enamel was brushed for $5 \mathrm{~min}$ using an electric toothbrush before being immersed in a remineralization solution. We evaluated the micromorphology and elemental levels (wt\%) of ions present in the toothpaste and on the layer formed over the enamel following the treatment. The surface morphology was assessed using scanning electron microscopy (SEM). The elemental analyses were performed using an energy-dispersive X-ray spectrometer (EDS). Results: Scanning electron micrographs of the toothpaste demonstrated a uniform size distribution of regular-shaped fillers sparsely organized in nanoclusters. Elemental analysis of the toothpaste's formulation demonstrated the presence of $\mathrm{Si}$ (silicon), Na (sodium), P (phosphorus), and F (fluorine), among others. We also detected a mineral layer that had formed on the treated enamel surface; the layer had a consistent uniform thickness of $\sim 14 \mu \mathrm{m}$. Conclusion: Based on the results, it can be stated that REFIX technology modifies the surface and subsurface of the enamel structure, forming a Si-rich mineral layer.
\end{abstract}

\section{KEYWORDS}

Dental enamel; Dentifrice; Scanning electron microscopy; Tooth remineralization.

\section{RESUMO}

Objetivo: Este estudo in vitro objetivou caracterizar o teor de minerais e a morfologia das partículas de um dentifrício fluoretado contendo tecnologia REFIX e o teor de minerais e a morfologia da superfície do esmalte tratada com este produto. Material e Métodos: Blocos de esmalte bovino $(n=5)$ foram obtidos $(4 \times 4 \times 6 \mathrm{~mm})$, desmineralizados (lesão de cárie artificial) e tratados (ciclagem de pH e escovação com dentifrício). Durante a ciclagem de $\mathrm{pH}$ de 7 dias (desmineralização e remineralização levaram 6 h e 18 h, respectivamente), o esmalte foi escovado por 5 min com uma escova dental elétrica antes de ser imerso em uma solução de remineralização. Avaliou-se a micromorfologia e os níveis elementares (\% em peso) dos íons presentes no dentifrício e na camada formada sobre o esmalte após o tratamento. A morfologia da superfície foi avaliada por meio de microscopia eletrônica de varredura (MEV). As análises elementares foram realizadas usando um espectrômetro de energia dispersiva de raios-X (EDS). Resultados: A análise por MEV do dentifrício demonstrou uma distribuição de tamanho uniforme de partículas de forma regular que foram organizados esparsamente em "nanoclusters". A análise elementar da formulação do dentifrício demonstrou a presença de Si (silício), $\mathrm{Na}$ (sódio), P (fósforo) e F (flúor), entre outros. Observou-se também uma camada mineral na superfície de esmalte com espessura uniforme consistente em torno de $14 \mu \mathrm{m}$. Conclusão: De acordo com os resultados, conclui-se que a tecnologia REFIX modifica a superfície e subsuperfície da estrutura do esmalte, formando uma camada mineral rica em silício.

\section{PALAVRAS-CHAVE}

Esmalte dentário; Dentífricos; Microscopia eletrônica de varredura; Remineralização dentária. 


\section{INTRODUCTION}

It has been proposed that biomimetic approaches, different mechanisms that reproduce the mineralization process [1], are claimed to improve the enamel remineralization [2]. This mechanism was possible by associating ionic compounds in combination with fluoride [3]. In this manner, there are several oral care products with active ingredients to protect teeth against the enamel demineralization associated with fluoride [4]. There are constant efforts on the research, development, and innovation of new products aimed at reducing enamel demineralization and at enhancing the enamel remineralizing ability of these formulations [5]. In this manner, companies have changed the toothpaste formulations have enabled by adding a variety of active ingredients, which ultimately increase the effectiveness of the toothpastes [6].

The main inorganic constituent of dental enamel is hydroxyapatite $\mathrm{Ca}_{10}\left(\mathrm{PO}_{4}\right)_{6}(\mathrm{OH})_{2}$ [7]. Biological apatite is also characterized by the presence of other ions, such as magnesium $\left(\mathrm{Mg}^{2+}\right)$, potassium $\left(\mathrm{K}^{+}\right)$, sodium $\left(\mathrm{Na}^{+}\right)$, zinc $\left(\mathrm{Zn}^{2+}\right)$, manganese $\left(\mathrm{Mn}^{2+}\right)$, orthosilicate $\left(\mathrm{SiO}^{4-}\right)$, and chloride $\left(\mathrm{Cl}^{-}\right)$[8], partially substituting calcium ( $\mathrm{Ca}$ ) ions, phosphate $(\mathrm{P})$ ions, and/or hydroxyl ions $\left(\mathrm{OH}^{-}\right)$in the crystal structure [9]. The remineralization process can be enhanced by the substitution of low levels of ionic species, such as carbonate and fluoride ions [6]. In addition, the bioactivity of hydroxyapatite is enhanced by the substitution of silicon into the remineralizing hydroxyapatite molecular structure [10]. These ionic changes are regarded to occur at the hydroxyapatite surface [9], but it has also been evaluated the potential of fluoride toothpastes to provide hydroxyapatite regeneration deeper into the enamel subsurface [11]. It has been advocated that replacing the hydroxyl ions in the enamel structure with fluoride and other ions increases the hardness, stabilizing the hydroxyapatite crystals and conferring protection against changes to lower critical salivary $\mathrm{pH}$ (5.5-5.2) in the oral cavity [8].

Recently, a proprietary technology named REFIX was developed, comprising a fluoride toothpaste associated with phosphates and silica. The manufacturer claims that this association favors the formation of a fluoridated apatite and the deposition of a silicate layer, which is also formed deeper into the enamel tissues and in the open dentin tubules. This claimed ionic change seems to reduce hydroxyapatite solubility, decreasing the dentin fluid movement, and improving its mechanical properties. In this manner, this mechanism also helps to protect against the consequences of dentin hypersensitivity [12]. The present in vitro study evaluated the mineral content and surface morphology of enamel surfaces treated with fluoridated REFIX technology-containing toothpaste. We also characterized the elemental content of the toothpaste.

\section{MATERIALS AND METHODS}

\section{Specimen preparation for microscopic analysis}

Bovine incisor teeth were sectioned to obtain enamel blocks $(4 \times 4 \times 6 \mathrm{~mm})$ using a rotating diamond blade (Extec, Enfield, CT, USA) under water lubrication in a cutting machine (IsoMet 1000, Buehler, Lake Bluff, IL, USA). The blocks $(\mathrm{n}=5)$ were subsequently embedded in epoxy resin (EpoxiCure Epoxy Resin and Hardener, Buehler). The block surfaces were subsequently wet-polished with 600-grit SiC (silicon carbide) paper at low speed and with 1,200-grit SiC paper at high speed using a polishing machine (Single Grinder Polisher, Buehler). A final polishing was performed with $1-\mu \mathrm{m}$ diamond paste and wet felt wheels.

\section{Caries-like lesion formation}

In order to demineralize the enamel surface to produce caries-like lesions, the blocks were immersed in $30 \mathrm{~mL} 50 \mathrm{mM}$ acetate buffer solution containing $3 \mathrm{mM} \mathrm{CaCl} \cdot \mathrm{H}_{2} \mathrm{O}$, $3 \mathrm{mM} \mathrm{KH}_{2} \mathrm{PO}_{4}, 50 \mathrm{mM}$ lactic buffer, and $6 \mu \mathrm{M}$ methylhydroxydiphosphate (MHDP) at pH 5.0 for 5 days [13].

\section{$\mathrm{pH}$ cycling}

After demineralization, the enamel blocks underwent $\mathrm{pH}$ cycling by interchanging a demineralization solution $\left(1.5 \mathrm{mM} \mathrm{CaCl}_{2}, 0.9 \mathrm{mM}\right.$ $\mathrm{KH}_{2} \mathrm{PO}_{4}, 50 \mathrm{mM}$ lactic buffer, $\mathrm{pH} 5.0,8 \mathrm{~h}$ ) and a remineralization solution $\left(5 \mathrm{mM} \mathrm{CaCl}_{2}, 0.9 \mathrm{mM}\right.$ $\mathrm{KH}_{2} \mathrm{PO}_{4}, 130 \mathrm{mM} \mathrm{KCl}, 20 \mathrm{mM}$ HEPES, $5 \mathrm{mM}$ $\mathrm{NaN}_{3}, \mathrm{pH} 7.0,16 \mathrm{~h}$ ) for 7 days [14]. Brushing was performed between the incubation with the remineralization and the demineralizing solutions $[15,16]$. The enamel blocks were 
treated with $30 \mathrm{~mL}$ toothpaste slurry solubilized in deionized water (3:1) using an electric toothbrush (Oral-B Vitality Precision Clean rechargeable toothbrush) for 5 min (120 cycles per minute, $22^{\circ} \mathrm{C}$ ). The specimens were brushed in linear movements with an axial load of $200 \mathrm{~g}$ [16]. The specimens were then rinsed with deionized water for $5 \mathrm{~s}$. The bovine enamel specimens were longitudinally sectioned under water-lubricated conditions, and both halves were evaluated using scanning electron microscopy (SEM) and elemental analysis.

SEM and energy-dispersive X-ray spectroscopy (EDS) characterization of the toothpaste and enamel cross-sections

The enamel halves were dehydrated in silica gel for $3 \mathrm{~h}$. Cross-sectional morphology analysis was then performed in a scanning electron microscope (VEGA3, TESCAN, LMU, Kohoutovice, Czech Republic) operating at $15 \mathrm{kV}$. The specimens were earlier sputter-coated with gold in a vacuum evaporator (MED 010; Balzers, Balzers, Liechtenstein), and then microscopically analyzed to obtain photomicrographs of the crosssectional morphology of the remineralized enamel halves ( $\times 1,000$ magnification). Representative micrographs were obtained for characterizing their morphological aspects. EDS point analysis (80 $\mathrm{mm}^{2}$, silicon drift detector [SDD], Oxford Instruments, Concord, MA, USA) was performed for qualitative elemental analysis of the enamel cross-sections, operating in high vacuum mode and an accelerating voltage of $15 \mathrm{kV}$. The mean obtained from randomly selected five points per sample (300 $\mu \mathrm{m}^{2}$ per point) was calculated.

The same analyses were performed for the toothpaste (Regenerador + Sensitive DentalClean, Rabbit Corp., Londrina, Brazil). After dehydration for 5 days, three samples of toothpaste $(250 \mathrm{mg}$ ) were mounted on aluminum stubs, gold sputtered, and evaluated at $\times 1000$ magnification under SEM with an accelerating voltage of $15 \mathrm{kV}$. The qualitative elemental analysis of the toothpaste was also performed using the same settings and at $\times 24000$ magnification under SEM with an accelerating voltage of $20 \mathrm{kV}$.

\section{RESULTS}

Figure 1 exhibits a photomicrography of the toothpaste, which demonstrated a uniform

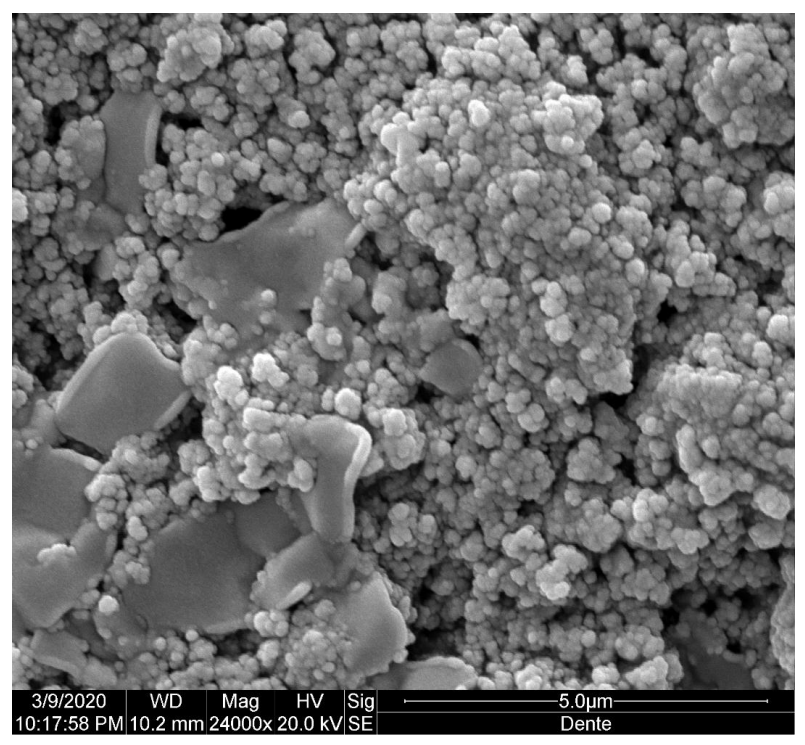

Figure 1 - Scanning electron micrograph of the toothpaste demonstrating the uniform size distribution of regular-shaped fillers sparsely organized in nanoclusters.

size distribution of regular-shaped fillers that were sparsely organized in nanoclusters. Figure 2 presents representative SEM/EDS analyses of the toothpaste. Figure 2A shows a representative photomicrography of the toothpaste and the elemental mapping at higher magnification, showing the complexation of the chemical elements; Figure 2B shows the colored squares of the elemental analysis of the toothpaste; Figure $2 \mathrm{C}$ shows a table of the elemental distribution in weight $\%$ observed in the toothpaste. Except for the higher percentages of ions $\mathrm{C}$ and $\mathrm{O}$, Si (9.39\%) had the highest mean weight $\%$ in the toothpaste. Other ions were also found in the toothpaste, such as $\mathrm{Na}(1.1 \%), \mathrm{P}$ (0.56\%), and F (fluorine, 0.15\%).

Figure 3 presents representative SEM/EDS analyses of the enamel cross-sections. Figure 3A shows the morphological analysis of the remineralized subsurface enamel, highlighting a greenish, silicon-rich superficial layer formed after the treatment; Figure 3B shows a table of the elemental distribution in weight $\%$ observed in the remineralized enamel, and a representative image of the color-coded distribution of the elements. The main elements observed in the mineralized layer formed onto the enamel were $\mathrm{Si}$ (black arrows), with a relative weight $\%$ of $0.71 \%$, which apparently formed a chemical complexation with Ca (31.28\%), P (14.77\%), and O (34.27\%); Figure 3C displays a representative photomicrograph demonstrating 


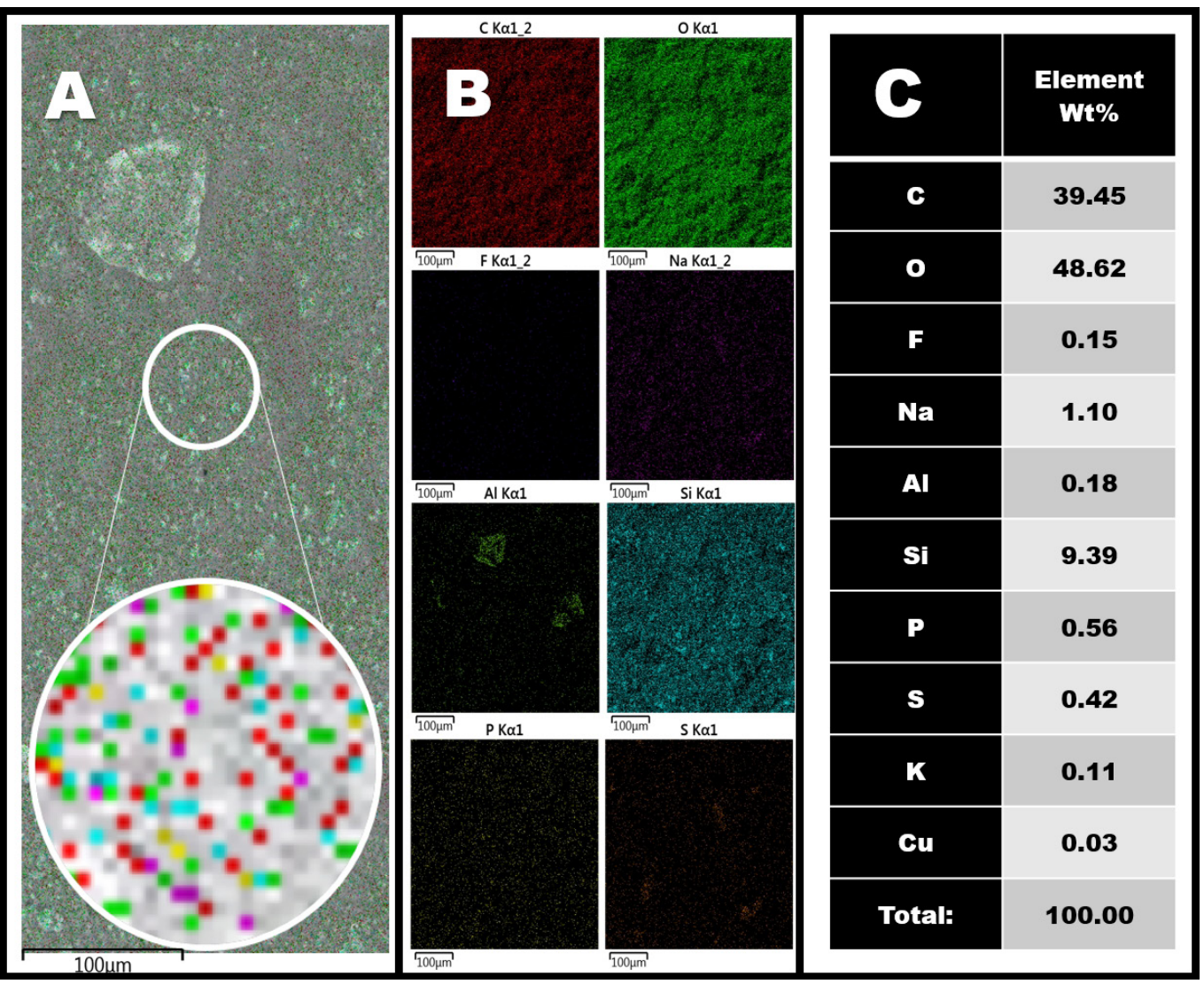

Figure 2 - (A) micrographs of the toothpaste and elemental mapping at higher magnification, demonstrating the complexation of the chemical elements; (B) the colored squares of the elemental analysis of the toothpaste according to the detected ions; (C) a table describing the elemental distribution in weight\% observed in the toothpaste; EDS analysis detected stronger signals for $\mathrm{Si}(9.39$ weight\%) and varied amounts of $\mathrm{Na}$, $\mathrm{P}$, and $\mathrm{F}$

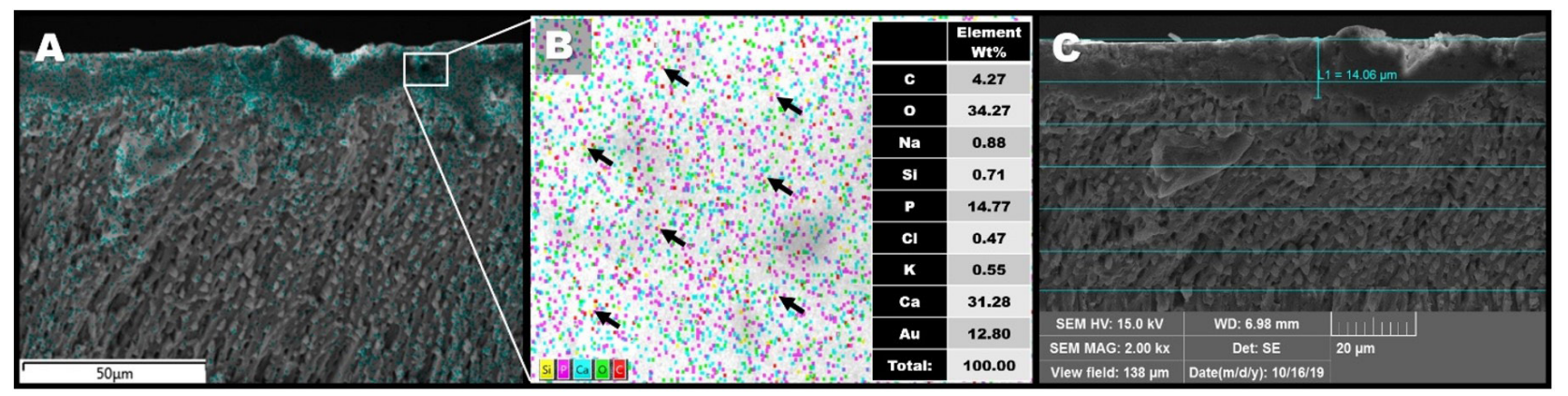

Figure 3 - (A) micrograph of the morphological evaluation of a cross-sectional area of the remineralized enamel, highlighting a greenish, siliconrich superficial layer formed after the treatment; (B) a table of the elemental distribution in weight\% observed in the remineralized enamel, and a representative image of the color-coded distribution of the elements; (C) a representative micrograph demonstrating the layer formed on the enamel surface $(\sim 14 \mu \mathrm{m})$

that a mineralized layer was formed at the treated enamel surface $(\sim 14 \mu \mathrm{m})$.

\section{DISCUSSION}

The present in vitro study characterized the mineral content and surface morphology of enamel surfaces treated with a fluoridated toothpaste containing proprietary REFIX technology. The manufacturer states that it represents a technology based on a multifunctional phosphatecontaining toothpaste with an acidified stabilized phosphate/fluoride complex, which is established especially in saliva $[12,16]$. The generation of new minerals containing calcium/phosphate/ fluorine is favored by the combination of saliva 
with dental tooth structures, which promotes the remineralization of the enamel surface and within subsurface carious lesions [16].

The toothpaste has an acidic $\mathrm{pH}$, which is used as a feature of the REFIX technology [16]. In an acidic environment, it is favored the formation of calcium phosphate crystals, which is regarded to be one of the reasons for its efficacy. It has been speculated that an acidic toothpaste would negatively affect the remineralization process in previously demineralized enamel tissue [16]. On the other hand, slightly acidic, fluoridecontaining products present no erosive potential [17]. In addition, other studies have proven that acidic products have similar or better anticaries effects in comparison to neutral formulations [18]. A previous study [16] also demonstrated that toothpaste containing REFIX technology contains $55.7 \%$ (by weight) particles, with an average particle size of $380.7 \mathrm{~nm}$, and low negative zeta potential $(-0.62 \mathrm{mV})$. These results are corroborated in Figure 1, which shows the uniform size distribution of regular-shaped fillers sparsely organized in nanoclusters. In addition, Figure 2 clearly demonstrates that the toothpaste contains, besides sodium fluoride, silicon. Silicates are usually added to toothpaste formulations, inducing the formation of calcium silicate, responsible for enhancing the mineralization processes of saliva via hydroxyapatite nucleation and mineral formation [19]. Silica is a component of bioactive glass and acts as a nucleation site for calcium and phosphate ion precipitation in the formation of hydroxyapatite [20]. Silica particles promote more rapid release of $\mathrm{Ca}$ and $\mathrm{P}$ [21] and low negative zeta potential in biological medium, which has important in vivo effects [20]. Replacing phosphate ions $\left(\mathrm{PO}_{4}\right)$ in the molecular structure of hydroxyapatite with silicate ions $\left(\mathrm{SiO}_{4}\right)$ leads to the formation of calcium silicate, which is deposited onto the eroded surface, thus allowing a protective layer due to the formation of hydroxyapatite [22].

Here, the mineral precipitates formed on the surface of the enamel block can be observed after the application of the toothpaste tested (Figure 3A). It appears that the silicon-containing enamel surface was induced by the toothpaste, which favored the formation of complexes of bioactive compounds formed by $\mathrm{Ca}, \mathrm{P}$, and $\mathrm{Na}$, as displayed in Figure 3B. EDS analysis also suggested the relative percentage weight of $\mathrm{Na}$ (mean $=0.88 \%$ ), which appears to favor the formation of a layer of hydroxycarbonate apatite on the enamel surface [23]. It has been demonstrated that the effectiveness of silicon is most evident when substitution occurs at $0.8 \mathrm{wt} \% \mathrm{Si}$, which is its highest level of metabolic activity [24]. Bioactive glass also induces quick complexation of $\mathrm{Na}, \mathrm{Ca}$, and $\mathrm{P}$, thus boosting mineral precipitation for remineralizing the enamel surface or for reducing the effects of the demineralization process [25]. Here, the manufacturer also states that another component of the toothpaste is tetrasodium pyrophosphate in association with $1450 \mathrm{ppm}$ of sodium fluoride [16]. The rationale that supports the oversaturation of the enamel surface associating calcium and phosphate is to avoid an additional loss of ions on the demineralized enamel surface. As a consequence, there is an increase in the resistance to the cariogenic process in the presence of fluoride ions [26]. The SEM analysis (Figure 3C) also demonstrated uniform mineral precipitation covering the enamel surface with a consistent thickness of $\sim 14 \mu \mathrm{m}$.

A previous clinical trial that evaluated the effectiveness of this toothpaste in 53 subjects [12]. The authors observed that the participants experienced a significant reduction in dentin hypersensitivity after 1 week of use. It was speculated that phosphate-mediated calcium fluoride and calcium silicate crystals were produced and placed on both the dentin surface and inside the dentin tubules. The authors explained that the continuous use of toothpaste favored the decrease of dentin hypersensitivity $88.3 \%$. The authors believe that the decrease in the sensitivity expressed by the participants could be due to deposition of crystals, which seems to progressively occlude the dentin tubules, reducing the dentinal fluid flow, and subsequently reducing the dentin hypersensitivity [12]. In another in vitro study [27], the mineral content and surface and cross-sectional morphology of enamel and dentin tissues treated with the same toothpaste were evaluated. The toothpaste with REFIX technology not only remineralized, but also effectively repaired the surface enamel. The results were also consistent in dentin, in which the dentin tubule diameter was progressively occluded until complete occlusion after one week, corroborating the results of a previous clinical trial study [12].

The present in vitro study evaluated the mineral content and filler particles morphology of a fluoridated toothpaste containing REFIX technology as well as the mineral content and the morphology 
of the enamel surface treated with this product. Considering the limitations of the present study, instead of using bovine teeth, it could be used with human teeth. Furthermore, other products, including a gold standard one, would allow other comparisons. In spite of these limitations, with this in vitro study, the results of previous studies [16,27] corroborate with our results. Complementary studies are still necessary to evaluate, especially in in situ and in vivo studies, the effectiveness of REFIX-containing technology toothpaste to remineralize the enamel and dentin tissues.

\section{CONCLUSION}

Based on the results of the present study, it can be stated that the REFIX technology modifies the surface and subsurface of the enamel structure, forming a Si-rich mineral layer.

\section{Acknowledgments}

The authors are grateful to Universidade Estadual de Londrina (UEL) for the use of the Scanning Electron Microscope.

\section{Conflict of Interest}

The authors have no proprietary, financial, or other personal interest of any nature or kind in any product, service, and/or company that is presented in this article.

\section{Funding}

The study was funded by the authors.

\section{Regulatory Statement}

None.

\section{REFERENCES}

1. Cao CY, Mei ML, Li QL, Lo EC, Chu CH. Methods for biomimetic remineralization of human dentine: a systematic review. Int J Mol Sci. 2015;16(3):4615-27. http://dx.doi.org/10.3390/ ijms16034615. PMid:25739078.

2. Volponi AA, Zaugg LK, Neves V, Liu Y, Sharpe PT. Tooth repair and regeneration. Curr Oral Health Rep. 2018;5(4):295-303. http:// dx.doi.org/10.1007/s40496-018-0196-9. PMid:30524931.

3. Xiao Z, Que K, Wang H, An R, Chen Z, Qiu Z, et al. Rapid biomimetic remineralization of the demineralized enamel surface using nano-particles of amorphous calcium phosphate guided by chimaeric peptides. Dent Mater. 2017;33(11):1217-28. http:// dx.doi.org/10.1016/j.dental.2017.07.015. PMid:28774431.
4. Farooq I, Ali S, Siddiqui IA, Al-Khalifa KS, Al-Hariri M. Influence of thymoquinone exposure on the micro-hardness of dental enamel: an in vitro study. Eur J Dent. 2019;13(3):318-22. http:// dx.doi.org/10.1055/s-0039-1697117. PMid:31618784.

5. Cardoso CA, Lacerda B, Mangueira DF, Charone S, Olympio KP, Magalhães AC, et al. Mechanisms of action of fluoridated acidic liquid dentifrices against dental caries. Arch Oral Biol. 2015;60(1):23-8. http://dx.doi.org/10.1016/j. archoralbio.2014.08.016. PMid:25244615.

6. Walsh T, Worthington HV, Glenny AM, Marinho VC, Jeroncic A. Fluoride toothpastes of different concentrations for preventing dental caries. Cochrane Database Syst Rev. 2019;3-5:CD007868. http://dx.doi.org/10.1002/14651858.CD007868.pub3. PMid:30829399.

7. Jones FH. Teeth and bones: applications of surface science to dental materials and related biomaterials. Surf Sci Rep. 2001;42(3):75-205. http://dx.doi.org/10.1016/S01675729(00)00011-X.

8. Pajor K, Pajchel L, Kolmas J. Hydroxyapatite and fluorapatite in conservative dentistry and oral implantology-a review. Materials (Basel). 2019;12(17):2683. http://dx.doi.org/10.3390/ ma12172683. PMid:31443429.

9. Turner IG. Ceramics and glasses. In: Narayan R, editor. Biomedical materials. New York: Springer Science + Business Media; 2009. p. 3-39. http://dx.doi.org/10.1007/978-0-387-84872-3_1.

10. Carrouel F, Viennot S, Ottolenghi L, Gaillard C, Bourgeois D. Nanoparticles as anti-microbial, anti-inflammatory, and remineralizing agents in oral care cosmetics: a review of the current situation. Nanomaterials. 2020;10(1):140. http://dx.doi. org/10.3390/nano10010140. PMid:31941021.

11. Schmidlin P, Zobrist K, Attin T, Wegehaupt F. In vitro re-hardening of artificial enamel caries lesions using enamel matrix proteins or self-assembling peptides. J Appl Oral Sci. 2016;24(1):31-6. http://dx.doi.org/10.1590/1678775720150352. PMid:27008255.

12. Vilhena FV, Polassi MR, Paloco EAC, Alonso RC, Guiraldo RD, D'Alpino PH. Effectiveness of toothpaste containing REFIX technology against dentin hypersensitivity: a randomized clinical study. J Contemp Dent Pract. 2020;21(6):609-14. http://dx.doi. org/10.5005/.jp-journals-10024-2847. PMid:33025927.

13. Buskes JA, Christoffersen J, Arends J. Lesion formation and lesion remineralization in enamel under constant composition conditions. A new technique with applications. Caries Res. 1985;19(6):490-6. http://dx.doi.org/10.1159/000260887. PMid:3865704

14. Lagerweij MD, ten Cate JM. Acid susceptibility at various depths of pH-cycled enamel and dentine specimens. Caries Res. 2006;40(1):33-7. http://dx.doi.org/10.1159/000088903. PMid:16352878.

15. Forcin LV, Oliveira TS, Tomaz PLS, Matochek MHM, Polassi MR, Vilhena $\mathrm{FV}$, et al. Enamel remineralization and surface roughness after treatment with herbal-containing toothpastes. J Clin Exp Dent. 2021;13(9):e849-58. http://dx.doi.org/10.4317/ jced.58025. PMid:34603613.

16. Tomaz PLS, Sousa LA, Aguiar KF, Oliveira TS, Matochek MHM, Polassi MR, et al. Effects of 1450-ppm fluoride-containing toothpastes associated with boosters on the enamel remineralization and surface roughness after cariogenic challenge. Eur J Dent. 2020;14(1):161-70. http://dx.doi. org/10.1055/s-0040-1705072. PMid:32168543.

17. Lussi A, Hellwig E. Risk assessment and causal preventive measures. Monogr Oral Sci. 2014;25:220-9. http://dx.doi. org/10.1159/000360612. PMid:24993270.

18. de Almeida Baldini Cardoso C, Mangueira DF, Olympio KP, Magalhaes AC, Rios D, Honorio HM, et al. The effect of $\mathrm{pH}$ and 
fluoride concentration of liquid dentifrices on caries progression. Clin Oral Investig. 2014;18(3):761-7. http://dx.doi.org/10.1007/ s00784-013-1031-2. PMid:23873319.

19. Moreno EC, Kresak M, Zahradnik RT. Fluoridated hydroxyapatite solubility and caries formation. Nature. 1974;247(5435):64-5. http://dx.doi.org/10.1038/247064aO. PMid:4462607.

20. Carvalho SM, Moreira CDF, Oliveira ACX, Oliveira AAR, Lemos EMF, Pereira MM. Bioactive glass nanoparticles for periodontal regeneration and applications in dentistry. In: Subramani K, Ahmed W, editors. Nanobiomaterials in clinical dentistry. 2nd ed. Amsterdam: Elsevier; 2019. p. 351-83. http://dx.doi.org/10.1016/ B978-0-12-815886-9.00015-2.

21. Hong Z, Merino EG, Reis RL, Mano JF. Novel rice-shaped bioactive ceramic nanoparticles. Adv Eng Mater. 2009;11(5):B25-9. http:// dx.doi.org/10.1002/adem.200800378.

22. Parker AS, Patel AN, Al Botros R, Snowden ME, McKelvey K, Unwin $P R$, et al. Measurement of the efficacy of calcium silicate for the protection and repair of dental enamel. J Dent. 2014;42(Suppl. 1):S21-9. http://dx.doi.org/10.1016/S0300-5712(14)50004-8. PMid:24993852.

23. Vieira-Junior WF, Ferraz LN, Pini N, Ambrosano G, Aguiar $F$, Tabchoury C, et al. Effect of toothpaste use against mineral loss promoted by dental bleaching. Oper Dent. 2018;43(2):190-200. http://dx.doi.org/10.2341/17-024-TR. PMid:29504887.

24. Burwell AK, Litkowski LJ, Greenspan DC. Calcium sodium phosphosilicate (NovaMin): remineralization potential. Adv Dent Res. 2009;21(1):35-9. http://dx.doi. org/10.1177/0895937409335621. PMid:19710080.

25. Deng $M$, Wen $H L$, Dong $X L, L i F, X u X, L i H$, et al. Effects of $45 S 5$ bioglass on surface properties of dental enamel subjected to 35\% hydrogen peroxide. Int J Oral Sci. 2013;5(2):103-10. http:// dx.doi.org/10.1038/ijos.2013.31. PMid:23743618.

26. Dai Z, Liu M, Ma Y, Cao L, Xu HHK, Zhang K, et al. Effects of fluoride and calcium phosphate materials on remineralization of mild and severe white spot lesions. BioMed Res Int. 2019;2019:1271523. http://dx.doi.org/10.1155/2019/1271523. PMid:31317022.

27. Vilhena FV, Oliveira SML, Matochek MHM, Tomaz PLS, Oliveira TS, D'Alpino PHP. Biomimetic mechanism of action of fluoridated toothpaste containing proprietary REFIX technology on the remineralization and repair of demineralized dental tissues: an in vitro study. Eur J Dent. 2021;15(2):236-41. http://dx.doi. org/10.1055/s-0040-1716781. PMid:33242916.

Paulo Henrique Perlatti D’Alpino

(Corresponding address)

Triplet Biotechnology Solutions, Bauru, SP, Brazil.

Date submitted: 2021 June 17

Email: paulodalpino@gmail.com

Accept submission: 2021 Oct 04 